\title{
Amyloid polyneuropathy in 2 patients after liver transplantation
}

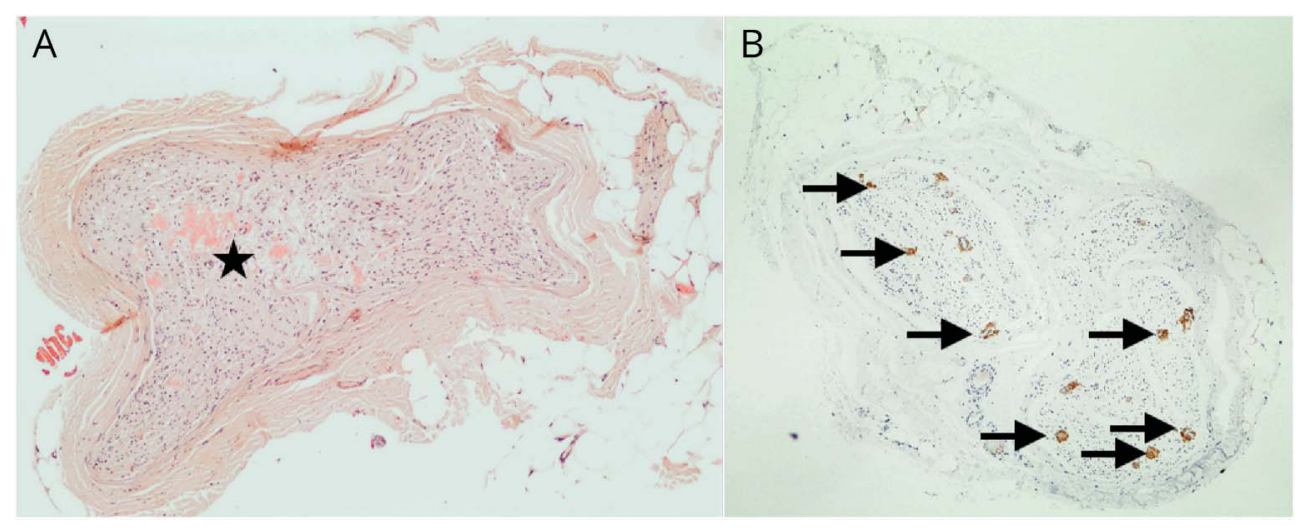

Transverse sural nerve sections, paraffin embedded. (A) Positive Congo red staining in the endoneural vessels (star). (B) Positive prealbumin (transthyretin) immunohistochemistry in the endoneurial vessels (arrows).

Domino liver transplantation, in which the liver from a patient with transthyretin-mediated amyloidosis (ATTR) is transplanted into another patient, is a well-established procedure. ${ }^{1,2}$ The figure is from 2 unrelated cases of liver transplant receptors from donors with ATTR who developed clinical polyneuropathy with weakness and paresthesia in lower extremities some years after the liver transplantation. In both cases, EMG showed distal sensory and motor polyneuropathy. Although amyloid neuropathy was the clinical suspicion, a muscle and nerve biopsy was performed in order to rule out other conditions.

\section{Author contributions}

Ainoa Ugarte: acquisition of data. Josep M. Grau: critical revision of the manuscript for important intellectual content. José C. Milisenda: study concept and design.

\section{Study funding}

No targeted funding reported.

\section{Disclosure}

The authors report no disclosures relevant to the manuscript. Go to Neurology.org/N for full disclosures.

\section{References}

1. Dixit N, Castano A, Farr MJ, et al. Rapidly progressive transthyretin-mediated amyloidosis in a domino liver transplant recipient of a Ser23Asn donor. J Clin Neuromuscul Dis 2016;17:142-145.

2. Adams D, Cauquil C, Labeyrie C. Familial amyloid polyneuropathy. Curr Opin Neurol 2017;30:481-489. 


\section{Neurology}

\section{Amyloid polyneuropathy in 2 patients after liver transplantation}

Ainoa Ugarte, Josep M. Grau and José C. Milisenda

Neurology 2018;90;38

DOI 10.1212/WNL.0000000000004777

This information is current as of December 28, 2017

Updated Information \& Services

References

Subspecialty Collections

Permissions \& Licensing

Reprints including high resolution figures, can be found at: http://n.neurology.org/content/90/1/38.full

This article cites 2 articles, 0 of which you can access for free at: http://n.neurology.org/content/90/1/38.full\#ref-list-1

This article, along with others on similar topics, appears in the following collection(s):

All Clinical Neurology

http://n.neurology.org/cgi/collection/all_clinical_neurology All Neurotology

http://n.neurology.org/cgi/collection/all_neurotology

EMG

http://n.neurology.org/cgi/collection/emg

Peripheral neuropathy

http://n.neurology.org/cgi/collection/peripheral_neuropathy

Information about reproducing this article in parts (figures,tables) or in its entirety can be found online at:

http://www.neurology.org/about/about_the_journal\#permissions

Information about ordering reprints can be found online:

http://n.neurology.org/subscribers/advertise

Neurology ${ }^{\circledR}$ is the official journal of the American Academy of Neurology. Published continuously since 1951 , it is now a weekly with 48 issues per year. Copyright Copyright (C) 2017 American Academy of Neurology. All rights reserved. Print ISSN: 0028-3878. Online ISSN: 1526-632X.

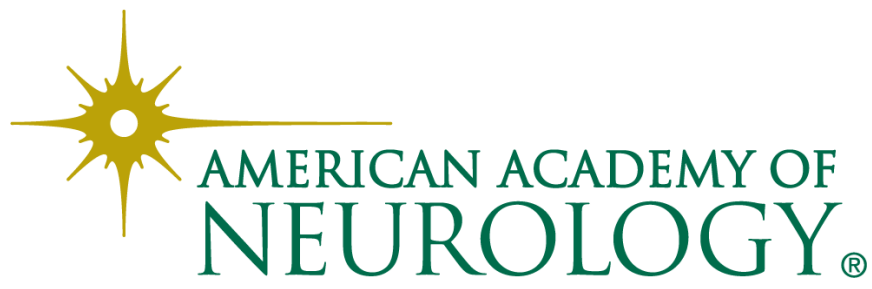

